Working Paper No. 07/05

\title{
Total Factor Productivity Growth On Britain's Railways, 1852-1912: A Reappraisal Of The Evidence
}

Nicholas F. R. Crafts,

Terence C. Mills,

\&

Abay Mulatu

(C) Nicholas F. R. Crafts

Department of Economic History

London School of Economics 
Financial support from the Economic and Social Research Council under grant R000239536 is gratefully acknowledged. We wish to thank Brian Mitchell for generously making available to us his data and Peter Cain for helpful advice. We have benefited from comments by Tony Arnold, Dudley Baines, Terry Gourvish and Peter Howlett. The usual disclaimer applies.

For further details about this project and additional copies of this, and other papers in the series, go to:

http://www.Ise.ac.uk/collection/economichistory/

Department of Economic History

London School of Economics

Houghton Street

London, WC2A 2AE

Tel: $\quad$ +44 (0) 2079557860

Fax: $\quad$ +44 (0) 2079557730 


\title{
Total Factor Productivity Growth On Britain's Railways, 1852-1912: A Reappraisal Of The Evidence
}

Nicholas F.R. Crafts', Terence C. Mills \& Abay Mulatu

\begin{abstract}
This paper revisits the issue of the productivity performance of preWorld War I Britain's railway system with an improved dataset and with modern time-series econometrics. We find a slowdown in TFP growth between 1850 and 1870, after which it stabilized at about 1.1\%. An analysis of company-level productivity rejects the claims that there was a regulation-induced revival of productivity performance in the railway sector after 1900 but, on the other hand, it supports the claim that there was some managerial failure during the period.
\end{abstract}

\section{Introduction}

A generation ago it was commonplace to allege that late nineteenth century Britain experienced 'entrepreneurial failure' and a climacteric in productivity growth (Landes, 1969; Saul, 1968). Now these claims are much more muted or nuanced as it has been recognised that the quantitative evidence offers relatively little support for them (Crafts, 2004a). In particular, the suggestion originally made by Phelps-Brown and Handfield-Jones (1952) that the climacteric resulted from the exhaustion of steam as a General Purpose Technology has been rejected (Crafts and Mills, 2004).

However, railways have not received the exoneration that has been given to most other sectors of the economy and the quality of their management and their productivity performance are still seen as, at best,

\footnotetext{
* Corresponding author. Department of Economic History, London School of Economics, Houghton Street, London WC2A 2AE, U.K. E-mail: n.crafts@lse.ac.uk. Tel.: +44 20 79556399. Fax: +44 207957730 .
} 
deficient and, at worst, dismal. Aldcroft (1968) saw railways as a prime example of managerial incompetence, reflected in failures to modernize their operating practices and in wasteful investment projects, and argued that this was reflected in the late nineteenth century by falling labour productivity and declining profitability. A partial defence of railway management was made by Irving (1978) and Cain (1988). The former noted that the true picture was one of increasing gross returns on capital and suggested that the problem was really only with operating costs. Both writers point to a substantial improvement of productivity after 1900 , especially in the operation of freight trains. Nevertheless, Cain concluded that "there was waste and inefficiency in the railway system of Great Britain between 1870 and 1914" (1988, p. 120).

The most recent assessment of railway management based on financial performance is that of Arnold and McCartney (2005). They conclude that returns to investors were consistently disappointing and that any increase in the net return on capital after 1900 was slight as mean returns on capital employed for the industry as a whole were below 4\% throughout the period 1892-1912. Arnold and McCartney argue that management incurred unnecessary costs and paid relatively little attention to creating shareholder value.

Railway management was undoubtedly affected by regulation. In the 1880s, railways incurred extra costs in an attempt to stave off regulation by improving service quality (Irving, 1978). Effective price control was not introduced until the Railway and Canal Traffic Act of 1894 but even then, at first, railway companies believed this to be rate of return regulation with cost pass-through. Following a test case in 1899, however, it became clear that the Act was being interpreted to freeze charges and, as inflation resumed, this threatened profits. Cain (1988) suggested that this forced railway managers to expend more effort to control costs and to 
improve productivity with a view to reassuring shareholders. Thus, in his view, tightened regulation after 1900 acted as an antidote to principalagent problems in large companies where ownership was separated from control. Even then, however, management was distracted by lobbying of government with a view to being able to solve their problems through mergers.

The principal evidence considered by Arnold and McCartney, Cain, and Irving relates to financial returns, which reflect but do not equate to productivity performance. Trends in railway productivity are central to these judgments of performance. Aldcroft's account of productivity trends was based on a measure of labour productivity derived from Phelps-Brown and Handfield-Jones (1952) which has subsequently been discredited. In fact, the data available to construct productivity indices are problematic in several respects. The first serious attempt to measure total factor productivity (TFP) growth was made by Hawke (1970). His estimates were later refined and extended from 1890 to 1910 by Foreman-Peck (1991). The Edwardian period was subjected to detailed scrutiny by Dodgson (1993), who constructed TFP growth estimates for each of 14 major railway companies.

Although the series that have been used for capital stock, employment and output at the national level all have serious weaknesses, and trends in the TFP estimates have never been analysed using modern time-series econometrics, the most recent overview has used the productivity evidence to re-assert a highly-critical view of railway management and to resist the suggestion that tighter regulation led to better productivity performance after 1900. Foreman-Peck and Millward state that "total factor productivity growth ... declined continuously after 1870 becoming negative in the Edwardian period", "the total factor productivity results are not consistent with an Edwardian recovery in 
railway performance", and "organization and customs that had been appropriate to one epoch of railway technology persisted when opportunities and challenges changed. Inertia was encouraged by an absence of competition ..." (1994, p. 88, 89, 90). Dodgson found substantial differences in productivity performance across his sample of companies and concluded that there was a "failure of Edwardian railway regulation" (1993, p. 176).

In this paper, we construct a new TFP index for Britain's railways, drawing heavily on unpublished estimates of the net capital stock and expenditures on wages in 30 major railway companies made by Brian Mitchell and based on revised estimates for the transport of freight. We use this index to conduct an econometric analysis of each of capital, labour and total factor productivity. We also examine the performance of individual railway companies for the period 1893-1912 for which adequate data are available and attempt to measure this on a basis as consistent as possible with our national estimates. This permits further insights into the impact of regulation as well as providing a perspective on the evaluations in the literature of various companies' performance.

In particular, we address the following specific questions:

1) What was the chronology of TFP growth in Britain's railways prior to World War I?

2) Does the evidence on productivity performance support the claim that regulation had a favourable impact after 1900 but not before?

\section{A New Total Factor Productivity Index}

This section describes and presents our new TFP index and its components for the British railway system prior to World War I. We then 
go on to compare the results with the earlier estimates made by Dodgson (1993), Hawke (1970) and Foreman-Peck (1991).

Estimates of railway output growth present serious difficulties. ${ }^{1}$ Ideally, in common with Dodgson (1993), we would like to create an index based on revenue-weighted estimates of passenger-miles and freight tonmiles, with the latter distinguishing between minerals, which generated very low receipts, and merchandise. Following Dodgson (1993), we use passenger train miles taken from the Railway Returns. This source also gives data on revenue for each of these types of output, and thus permits calculation of the required revenue shares, and for tons of minerals and merchandise carried. $^{2}$ As Dodgson points out, distinguishing between minerals and general merchandise matters because the latter was a declining proportion of traffic, and failure to separate out these two types of freight appears to be a serious weakness in Foreman-Peck's estimates besides making them non-comparable with those of Dodgson.

For freight, the problem comes in calculating ton-miles, which requires an estimate of the average length of haul, and it is here that the major differences with previous studies lie. We have based our estimates of haul length for 1871 to 1912 on estimates for receipts per ton-mile for different types of freight given by Paish (1902). He found that the most common estimate for these in the companies that he studied was $0.7 \mathrm{~d}$ for minerals and 2.0d for merchandise in 1900, and he reported that these rates were also typical of the whole period 1880 to 1900 for the largest

\footnotetext{
${ }^{1}$ In common with all the other studies cited in this paper, in measuring output growth we do not address the issue of the quality of service provided by the railways. Clearly, this improved over time, especially for passengers with regard to comfort and speed, and was a dimension on which railway companies might compete.

${ }^{2}$ For the years 1852 to 1855 we estimated tons carried from revenue on the basis of a regression estimated for the next 10 years. Similarly, we interpolated for missing and apparently deficient data on tons carried in 1868, 1869 and 1870 using the revenue data. The revenue shares for the middle year (1882) are 0.43 for passengers, 0.25 for minerals and 0.32 for merchandise.
} 
company, the London and North Western Railway. Using these rates per ton-mile, together with receipts and tons carried for different classes of traffic from the Railway Returns, produces estimates of ton-miles and thus haul length. Basing the estimates back to 1871 on these $0.7 \mathrm{~d} / 2.0 \mathrm{~d}$ receipts goes beyond the period covered by Paish, but does not seem unreasonable since it produces an average receipt of $1.14 \mathrm{~d}$ per ton-mile, just slightly below the estimate in Hawke (1970) of 1.21d. Similarly, assuming that the same $0.7 \mathrm{~d} / 2.0 \mathrm{~d}$ receipts were still representative of the years through to 1912 is stretching the use of Paish's data, but it seems likely that any bias is small. ${ }^{3}$

Prior to 1871 , the only estimates of haul length that we have are those of Hawke (1970), who obtained a reasonably solid estimate for minerals of 31.5 miles in 1865 using evidence from the Royal Commission on Coal, and complemented it with a speculative estimate for other traffic. Hawke also used an estimate of 22.5 miles for all traffic in 1847 which originally appeared in Lardner (1855) and which came from unpublished estimates made by the Railway Commissioners and was consistent with a plausible average receipts figure of $1.67 \mathrm{~d}$ per ton-mile. Similar to Hawke, we have assumed a steady trend increase between 1847 and 1871.

The resulting estimates for haul length are shown in Table 1, where the earlier estimates of Cain (1988) and Hawke (1970) are also reported, together with the implied average receipts per ton-mile for all freight. Our procedures seem to be consistent with more of the available evidence than either of these earlier writers. In particular, the following points should be noted. First, the estimates are similar to those of Cain (1988) for the post-

\footnotetext{
${ }^{3}$ Cain (1980) suggests that rates fell after 1900 based on the detailed statistics for the North Eastern Railway Company presented in Irving (1976). If these reductions were typical of other companies, then by 1911 receipts for minerals would have fallen to $0.69 \mathrm{~d}$ and for merchandise to $1.90 \mathrm{~d}$ per ton-mile. Incorporating this adjustment would only add about 2 per cent to the increase in total output between 1900 and 1912.
} 
1870 period but are more solidly grounded in explicit assumptions about receipts for different classes of freight. Second, unlike Cain (1988), and following him Foreman-Peck (1991), they also explicitly distinguish between minerals and merchandise, which matters given the changing composition of traffic and the much higher charges for the latter category. Third, the estimates for minerals haul in 1865 and average haul for 1900 are very similar to those in Hawke (1970) and Paish (1902) respectively. ${ }^{4}$ Fourth, the rising haul lengths suggested by Hawke (1970) after 1871 are clearly implausible because they imply big falls in average receipts and are inconsistent with the data in Paish (1902). Fifth, the decline in mineral hauls after the mid-1870s reflects the growing competition from coastal shipping on long hauls and is epitomized by a declining share of London's coal traffic (Armstrong, 1987). Sixth, the implied receipts for 1852 are a bit lower than the estimate of Lardner (1855) for 1847.

Three inputs are aggregated to form Total Factor Input (TFI), namely capital (with a weight of 0.63), labour (0.34) and coal (0.03). The weights are based on cost shares at mid-period (1882) taken from Mitchell's worksheets. ${ }^{5}$ Estimates of the net capital stock in each year are obtained directly from Mitchell and they are consistent with the estimates for gross capital formation published in Mitchell (1964), together with his assumed lifetimes for each type of capital asset. ${ }^{6}$ For our index of labour inputs, we follow Hawke (1970, p.262) to obtain estimates for 1852 to 1860, 1873 and 1884, and also have estimates for 1898, 1901, 1904, 1907 and 1910 from Munby and Watson (1978). We have interpolated between these years

\footnotetext{
${ }^{4}$ The data in Paish (1902) imply an average haul length of 26.4 miles according to Cain (1980, p. 12).

${ }^{5}$ Foreman-Peck and Hawke use weights of $0.73,0.23$ and 0.04 . The difference in weighting makes no material difference. Mitchell's worksheets were complied from the accounts of 30 major railway companies and formed the basis of his estimates of capital formation which appeared in Mitchell (1964).

${ }^{6} 30$ years for rolling stock and 100 years for permanent way and works.
} 
using the annual estimates of expenditure on wages and salaries in Mitchell's worksheets. For coal, we have linearly interpolated between the years where coal consumption is known and reported in Mitchell (1988). ${ }^{7}$ We report the annual series that are obtained as the first three columns of Table 2, while TFI is in column 4.

We believe that the annual series for capital and labour inputs are superior to those used previously and they are actually the first on an annual basis for 1890-1912. With regard to the growth of capital inputs, our estimates are very similar indeed to those of Hawke (1970) for 1852 to 1890 , which were based on unpublished work by Kenwood. Our estimates show lower growth of capital inputs in every decade from 1870 to 1910 than those in Foreman-Peck (1991), even though his estimates were based on Mitchell (1964). With regard to employment, Hawke (1970) used a regression to extrapolate from the known data points but this does not seem to fit particularly well, while Foreman-Peck (1991) adds to these estimates only at 10-yearly intervals, apparently using similar sources to us. Differences between the three sets of estimates in the long run trends of employment growth are, however, not very great.

In Table 3 we present our index of TFP and the series of labour and capital productivity. Table 4 displays endpoint calculations for each decade of rates of growth of output, TFI and TFP and also of labour productivity, in order to get an initial sense of the timing of any deceleration in productivity growth and to highlight the differences between our estimates and those of earlier writers.

Our estimates do suggest a decrease in TFP growth from the 1850s through each decade to the 1880s, with a modest recovery after 1900 . Over the whole period from 1852 to 1912 labour productivity increases by

\footnotetext{
${ }^{7}$ These years are $1855,1869,1887,1903$ and 1913 . This is obviously a crude procedure but the weight on coal is so small that any bias must be trivial.
} 
less than 3 per cent. During this period labour productivity growth is somewhat erratic and is actually strongest after 1900. Compared with Hawke, our estimates show lower productivity growth with the exception of the 1860s. This is primarily because our estimates of output growth are lower and, in turn, this results especially from our rejection of Hawke's inference of rising average haul length after 1870. Compared with Foreman-Peck, we have lower TFP and labour productivity growth except in the 1890s. Both in the 1880 s and 1900s our estimates of output growth are lower and this primarily reflects our splitting freight into separate minerals and merchandise components. Compared with Dodgson, we have higher TFP and labour productivity growth after 1900 because our estimates of TFI growth are lower than his. It must be remembered, however, that the basis of these estimates is somewhat different, see section 4.

\section{Modeling Trend Growth Rates}

In this section, we model the time series for output, capital and labor productivity and TFP with the aim of estimating their trend rates of growth. The general framework that we employ is to suppose that an observed time series $Z_{t}$ can be decomposed as

$$
Z_{t}=S_{t}+N_{t}
$$

with the objective being to use the data on $Z_{t}$ to estimate the unobserved component series $S_{t}$ and $N_{t}$, which may be taken to represent 'signal plus noise'. Models for the components may be defined within the setup of the basic structural model (BSM), which has been used in previous studies of 
output growth by Crafts, Leybourne and Mill (1989) and Crafts and Mills $(1994,1996)$. This assumes that the signal is the sum of trend and cycle components, i.e., $S_{t}=T_{t}+C_{t}$. The trend, $T_{t}$, follows a random walk with a stochastic slope, which also follows a random walk:

$$
\begin{aligned}
& T_{t}=T_{t-1}+\beta_{t-1}+v_{1 t} \\
& \beta_{t}=\beta_{t-1}+v_{2 t}
\end{aligned}
$$

Generally, the cyclical component, $C_{t}$, is formulated as a stochastic combination of sine and cosine waves, but for the data being analysed here, it was found that a simpler first order auto-regression is appropriate:

$$
C_{t}=\rho C_{t-1}+w_{t}
$$

where $0<\rho<1$. The cycle thus has a characteristic decay time scale of $-1 / \ln \rho$, which may be interpreted as the expected length of time a shock to $C_{t}$ takes to dissipate. The level and slope innovations, $v_{1 t}$ and $v_{2 t}$, the cycle innovation, $w_{t}$, and the noise component $N_{t}=u_{t}$ are assumed to be mutually uncorrelated white noises.

If both level and slope innovation variances, $\sigma_{1}^{2}$ and $\sigma_{2}^{2}$, are zero, then $\beta_{t}=\beta_{t-1}=\beta$ and the trend will be the deterministic linear trend

$$
T_{t}=\mu+\beta t
$$


where $\mu=T_{0}$ is the 'initial condition'. If $\beta=0$ as well, then $T_{t}$ is constant. If just $\sigma_{2}^{2}=0$, the slope is fixed and the trend reduces to a random walk with drift:

$$
T_{t}=T_{t-1}+\beta+v_{1 t}
$$

If, however, just $\sigma_{1}^{2}=0$, then the trend becomes

$$
\Delta^{2} T_{t}=v_{2, t-1}
$$

which is an integrated random walk and is often referred to as the 'smooth trend' model, since fitted models of this type often produce a signal that is relatively smooth. The BSM can be fitted and the components estimated using the software provided by the STAMP package: see Koopman et al (2000) for technical details and Mills (2003) for a convenient review.

Logarithms of each of the four series were taken to help induce homogeneity of variance and to linearize trend behaviour where it exists.

\subsection{Output}

Figure 1 plots log output (denoted $Z_{t}$ below) for the period $1852-$ 1912. A BSM fitted to $Z_{t}$ resulted in the estimates

$$
\hat{\sigma}_{1}=0.0262 \quad \hat{\sigma}_{2}=0.0052 \quad \hat{\sigma}_{w}=\hat{\sigma}_{u}=0
$$

thus showing that there are no cyclical or noise components, so that $T_{t}$ and $Z_{t}$ are identical. A plot of the slope, $\beta_{t}$, which may be interpreted as a trend growth component, is shown in Figure 2. This declines throughout 
the sample, from around $6.5 \%$ in the 1850 s to $1.3 \%$ by 1912 , with a fairly stable period of $2.5 \%$ between the early 1880 s and the late 1890 s. This, of course, leads to the flattening trend shown in Figure 1. It appears that railways are another example of the 'inverted-U' or 'hump' shape for trend growth, similar to other steam-intensive sectors such as coal, cotton and iron (Crafts and Mills, 2004, p. 164). ${ }^{8}$

\subsection{Capital Productivity}

Figure 3 shows the logarithms of capital productivity. The best fitting BSM has $\hat{\sigma}_{1}=0.0300, \hat{\sigma}_{2}=0.0025$ and $\sigma_{w}=\sigma_{u}=0$ and thus is of the same form as output, so that there are no cyclical or noise components and $T_{t}$ and $Z_{t}$ are identical. A plot of the estimated slope $\hat{\beta}_{t}$ is shown in Figure 4 , where it is seen that trend growth fell from 3\% per annum at the start of the 1850 s to $1.5 \%$ by the beginning of the 1880 s, after which it stabilized at this value until the end of the sample.

\subsection{Labour Productivity}

Figure 5 shows the logarithms of productivity with the estimated 'level' superimposed. This is a consequence of the best fitting BSM, which has $\sigma_{1}=\sigma_{2}=\sigma_{u}=\beta=0$ and $\hat{\sigma}_{w}=0.0343$, and implies the model

$$
\begin{aligned}
& Z_{t}= \begin{array}{l}
4.549+C_{t} \\
(0.019)
\end{array} \\
& C_{t}= 0.762 C_{t-1}+w_{t} \\
&(0.086)
\end{aligned}
$$

\footnotetext{
${ }^{8}$ We only observe the right hand side of the inverted $U$ in our output index, but if that is spliced to Hawke's output series for 1840 to 1852 then this result is more apparent.
} 
Thus the trend level is $\hat{\mu}=4.55$, around which are deviations following a first order auto-regression with parameter 0.76 . The characteristic decay time scale of these deviations is 3.6 years, which is clearly seen in the figure. The implied stationarity of this series is also an outcome of conventional modelling, which would typically begin with testing for the presence of a unit root. A battery of such tests tend to reject such a null hypothesis and, if we assume a null of stationarity around a constant level, then tests cannot reject this null. It is therefore quite legitimate to assume that $Z_{t}$ is stationary around a fixed level, which is equivalent to the model fitted above.

\subsection{TFP}

Figure 6 shows the logarithms of TFP. The best fitting BSM has $\hat{\sigma}_{1}=0.0261, \hat{\sigma}_{2}=0.0021$ and $\hat{\sigma}_{u}=0.0078$, so that, unlike output and capital productivity, there is a noise component. However, this noise component is very small, and hence $Z_{t}$ and $T_{t}$ are very close to each other. A plot of the estimated slope $\hat{\beta}_{t}$ is shown in Figure 7 , where it is seen that trend growth fell from $2.3 \%$ per annum in the 1850 s to $1.1 \%$ by the beginning of the 1880s, after which it stabilised at this value until the end of the sample.

In summary, trend output growth declines throughout the period from $6.5 \%$ to $1.3 \%$ per annum, except for the 1880 s and 1890 s, where it remained fairly constant at around $2.5 \%$. Trend labour productivity was constant throughout the period, so that trend growth is absent. Capital productivity and TFP trend growth both fell consistently until the early 1880s, after which both stabilized for the rest of the period at $1.5 \%$ and $1.1 \%$ per annum respectively.

The implications of these results are as follows. First, continuing growth in capital productivity throughout the period suggests that Irving 
(1978) was right to argue that claims that railway managers indulged in a spree of wasteful investment projects are mistaken. Second, there is a recovery in labour productivity after 1900, which the econometric evidence might suggest could be seen as an 'error correction'. This is consistent with the improvement in operating practices at that time noted by both Cain (1988) and Irving (1978). Third, trend growth in TFP is better than a reader of Foreman-Peck and Millward (1994) would suppose, since it stabilizes in the early 1880 s at $1.1 \%$ per year. On the other hand, these authors are right to say that there is no increase in TFP growth in the Edwardian period and it turns out that the apparent improvement shown by the endpoints calculation in Table 4 is misleading. There is no support in this analysis for a suggestion that tighter regulation led to faster TFP growth after 1890.

\section{TFP Growth in 14 Railway Companies}

The major source of the data available to analyze TFP growth at the company level is the Railway Returns, published, annually, by the Board of Trade. With respect to output, the Returns provide data for each company on passenger train miles, merchandise tons, mineral tons, and revenue from each of the three types of output, which are used for the calculation of the required shares to derive total output. We converted each category of freight tons to ton miles in the same manner as we did for the aggregate analysis, i.e. using Paish's (1902) rate per ton mile figures of $0.7 d$ and $2 d$ for minerals and merchandise freight, respectively. As noted in section 2, receipts per ton-mile were falling after 1900 , so this will bias output and TFP growth down slightly. ${ }^{9}$

\footnotetext{
${ }^{9}$ The alternative is to follow Dodgson (1993) and assume constant haul lengths, although these are in fact likely to have changed somewhat, cf. Table 1. Adopting this
} 
Various sources are used to construct the growth rates of TFI. Following Dodgson (1993) we proxy capital input by total route miles which are provided in the Railway Returns. The same source provides data on annual expenditures on wages and coal, which we use to estimate, respectively, employment and fuel use by deflating using a price index. We used the Board of Trade wage index, based on average weekly earnings for 20 British railway companies, which goes back to 1898 and is given in Munby and Watson (1978, p. 58). We extended this back to 18931912 by interpolating from reported railway wages for 1891 from the Earnings and Hours Enquiry using wage data for bricklayers. With respect to coal prices the cost per ton of coal consumed in locomotive power is considered. Such information is available from the public record office (PRO RAIL 414 595) for 14 of the 15 companies under consideration. Following Dodgson (1993), estimates for the Taff Vale railway company and some missing data for the South Eastern railway company are obtained on the basis of a regression of cost per ton of locomotive coal for the companies with available information on fuel cost per train-mile.

The results reported in Table 5 show an average TFP growth between 1893 and 1912 of $0.7 \%$ per year, with 1900 to 1912 slightly lower at $0.6 \%$, which is slightly above the average of $0.4 \%$ that Dodgson (1993) found for the latter period. Average TFP growth is lower than in our national estimates (Table 4) and this comes from faster growth of TFI after 1900. Clearly, the national estimates are to be preferred since they derive from estimates of the capital stock rather than route miles and are anchored by estimates of employment rather than relying entirely on deflating the wage bill by an imperfect measure of wage rates. The value

alternative does not make any material difference with regard to any of the main points developed in this section. 
of Table 5 is in the information that it conveys about the dispersion of productivity performance.

The estimates in Table 5 indicate a wide range of TFP growth across these 14 companies - over the whole period 1893 to 1912 there is a gap of 0.8 percentage points per year between the best and the worst performer. This gap did not narrow after 1900 and in the years 1900 to 1912 three companies had TFP growth of less than or equal to $0.2 \%$ per year. Only two companies achieved an increase in TFP growth in 1900 to 1912 compared with 1893 to 1900 , whereas TFP growth fell in 11 cases. There is no evidence here to support the claim of a general revival in productivity performance after 1900.

Mulatu and Crafts (2004) have calculated efficiency scores for these 14 companies using a stochastic cost frontier model. A comparison of those results with the TFP growth estimates in Table 5 reveals weak inverse rank correlation between inefficiency in either $1893(r=-0.30)$ or 1900 ( $r=-0.24)$ and subsequent productivity performance. In other words, there is no tendency for the least efficient to catch up through faster TFP growth. This underlines, and indeed reinforces, Dodgson's point that there was a failure of railway regulation in this period. Some form of yardstick regulation, as practised for example by OFWAT in the case of the English water companies privatized in 1989 , would surely have produced a better outcome.

The results in Table 5 do not entirely support views expressed in the literature about the relative merits of different railway companies. It seems to be generally accepted that the North Eastern Railway was much the best-managed. ${ }^{10}$ Our estimates do indeed show that this company was

\footnotetext{
${ }^{10}$ Irving (1976) supports this assessment by comparing the increase in freight receipts per freight train mile between 1899 and 1912 across companies. It should be noted that there is only a weak correlation between this measure and our estimate of TFP growth ( $r$
} 
near the top of the TFP growth league table but over the years 1893 to 1912 it is slightly below Taff Vale and equal with Great Eastern and is only 0.5 percentage points above the mean for all 14 companies. The North Eastern's prowess appears to have been a little oversold. Over the same years both the South Eastern and the Great Central exhibit below average TFP growth which somewhat weakens the suggestion in Gourvish (1978) that the much-maligned Edward Watkin and James Forbes left their companies in a position to participate fully in a move to greater efficiency in the new century.

\section{Discussion}

While the Phelps-Brown and Handfield-Jones (1952) thesis of a steam-driven climacteric is not persuasive, there was a small reduction in steam's contribution to labour productivity growth after 1870, of 0.1 percentage points per year, according to the growth accounting study by Crafts (2004b). The revised estimates for productivity growth in railways do not change this estimate, although they imply that the total steam contribution should be revised down from $0.31 \%$ to $0.30 \%$ per year between 1850 and 1870 and from $0.41 \%$ to $0.40 \%$ per year from 1870 to 1910. The reduction in the contribution of railways between the two periods is nearly 0.2 percentage points per year, which more than accounts for the decrease in the total steam contribution. The other components (stationary steam engines and steamships) contributed more after 1870 than before. Railways did experience a productivity slowdown but, even so, trend TFP growth bottomed out at about 1.1\% per year after 1880, which exceeds the rate of TFP growth for the aggregate UK

$=0.25$ ) and this suggests that Irving's measure may not be a very good way to evaluate management performance in real cost reduction across all activity. 
economy in this period of a little under $0.5 \%$ per year (Feinstein et al., 1982). This suggests that pessimism about productivity performance on the railways should be kept in perspective.

Nevertheless, it seems that the exoneration of the late Victorian and Edwardian economy from the allegation of entrepreneurial failure announced by new economic historians (McCloskey and Sandberg, 1971) is problematic in the case of railways. Not only were there examples of seriously misconceived investment projects such as the Great Central Railway's London extension but, at the company level, there are big disparities in productivity performance. Mulatu and Crafts (2004) find a wide range of efficiency scores in the 1890s with no tendency for this to narrow in the Edwardian period and, in this context, the failure of the laggards to catch up the leaders through faster TFP growth is disappointing. The general argument stressed by McCloskey and Sandberg was that competition punished firms that failed to perform well. But, while this argument has general appeal, it does not really apply to the railway sector, in which barriers to entry were massive and tacit collusion was apparent (Cain, 1988). Across the whole industry, the absence of competition could be expected to lead to poor productivity performance in companies that lacked a dominant external shareholder (Nickell, 1996). And as Arnold and McCartney (2005) argue this would imply excessive costs and weak profitability in the railway system.

This highlights the potential importance of regulation as a spur to productivity improvement, as is strongly suggested by the experience of privatization of public utilities in the UK (Parker, 2004). Yet, although regulatory constraints may have played a role of this kind after 1900, as Cain (1988) claimed, the incentives given to greater efficiency were quite weak compared with what could have been introduced through pricecapping plus yardstick competition. The regulatory regime did not explicitly 
penalize under-performance and the squeeze imposed by frozen charges was quite modest in the low inflation environment of the Gold Standard.

\section{Conclusions}

We posed two explicit questions at the outset. Our answers are as follows.

First, on the basis of our new TFP index for British railways and a time-series analysis of its properties, we conclude that labour productivity was stationary over the long run while trend TFP growth fell steadily from a little under $2.5 \%$ per year in the 1850 s to about $1.1 \%$ per year in the early 1880s, at which rate it continued without any further decline till World War I.

Second, we believe that the record of productivity performance at the company level suggests that regulation did not have any significant positive impact after 1900. The absence of any catching-up by companies with relatively low initial levels of efficiency suggests a failure of railway regulation in this era. No doubt it would be anachronistic to have expected regulation to have been better designed but, in a sector where competition was quite weak, the upshot was that incumbent management was allowed a good deal of scope to be sleepy. 


\section{$\underline{\text { References }}$}

Aldcroft, D.H. 1968. The Efficiency and Enterprise of British Railways, 1870-1914. Explorations in Entrepreneurial History 5, 158-174.

Arnold, A.J. and McCartney, S. .2005. Rates of Return, Concentration levels and Strategic Change in the British Railway Industry, 18301912. Journal of Transport History, forthcoming.

Cain, P.J. 1980. Private Enterprise or Public Utility? Output, Pricing and Investment on English and Welsh Railways, 1870-1914. Journal of Transport History 1, 9-28.

Cain, P.J. 1988. Railways 1870-1914: the Maturity of the Private System. In Freeman M.J. and Aldcroft D.H. (Eds.), Transport in Victorian Britain. Manchester: Manchester University Press, 92-133.

Crafts, N. 2004a. Long-Run Growth. In: Floud R. and Johnson P. (Eds.), The Cambridge Economic History of Modern Britain, vol. 2. Cambridge: Cambridge University Press, 1-24.

Crafts, N. 2004b. Steam as a General Purpose Technology: a Growth Accounting Perspective. Economic Journal 114, 338-351.

Crafts, N.F.R., Leybourne, S.J. and Mills, T.C., 1989. Trends and Cycles in British Industrial Production, 1700-1913. Journal of the Royal Statistical Society, Series A, 152, 43-60.

Crafts, N.F.R. and Mills, T.C. 1994. The Industrial Revolution as a Macroeconomic Epoch: an Alternative View. Economic History Review 47, 769-775.

Crafts, N. and Mills, T.C. 2004. Was 19th Century British Growth SteamPowered?: the Climacteric Revisited. Explorations in Economic History 41, 156-171.

Dodgson, J.S. 1993. British Railway Cost Functions and Productivity Growth, 1900-1912. Explorations in Economic History 30, 158-181. 
Feinstein, C. H., Matthews, R. C. O., and Odling-Smee, J. C. 1982. The Timing of the Climacteric and its Sectoral Incidence in the UK, 18731913. In: Kindleberger C. P. and di Tella G. (Eds.), Economics in the Long View, vol. 2. Macmillan, London, 168-185.

Foreman-Peck, J. 1991. Railways and Late Victorian Economic Growth.

In: Foreman-Peck J. (Ed.), New Perspectives on the Late Victorian Economy. Cambridge University Press, Cambridge, 73-95.

Foreman-Peck, J. and Millward, R. 1994. Public and Private Ownership of British Industry, 1820-1990. Clarendon Press, Oxford.

Gourvish, T. R. 1978. The Performance of British Railway Management after 1860: the Railways of Watkin and Forbes. Business History 20, 186-200.

Hawke, G.R. 1970. Railways and Economic Growth in England and Wales, 1840- 1870. Clarendon Press, Oxford.

Irving, R.J. 1976. The North Eastern Railway Company 1870-1914: an Economic History. Leicester University Press, Leicester.

Irving, R.J. 1978. The Profitability and Performance of Britain's Railways, 1870-1914. Economic History Review 31, 46-66.

Koopman, S.J., Harvey, A.C., Doornik, J.A. and Shephard, N. 2000. STAMP 6: Structural Time Series Analyer and Predictor. Timberlake Consultants Ltd, London.

Landes, D.S. 1969. The Unbound Prometheus. Cambridge University Press, Cambridge.

Lardner, D. 1855. Railway Economy: A Treatise on the New Art of Transport, Its Management, Prospects and Relations. Harper \& Brothers, New York.

McCloskey, D. N. and Sandberg, L. 1971. From Damnation to Redemption: Judgments on the Late Victorian Entrepreneur. Explorations in Economic History 9, 89-108. 
Mills, T.C. 2003. Modelling Trends and Cycles in Economic Time Series. Palgrave Macmillan, Basingstoke.

Mills, T.C. and Crafts, N.F.R. 1996. Modeling Trends in Economic History. The Statistician 45, 153-159.

Mitchell, B.R. 1964. The Coming of the Railway and United Kingdom Economic Growth. Journal of Economic History 24, 315-336.

Mulatu, A. and Crafts, N. 2005. Efficiency Among Private Railway Companies in a Weakly Regulated System: The Case of Britain's Railways Before World War I. London School of Economics, Department of Economic History Working Papers, Large Scale Technological Change 08/05.

Munby, D. L. and Watson, A. H. 1978. Inland Transport Statistics: Great Britain 1900- 1970. Clarendon Press, Oxford.

Nickell, S. J. 1996. Competition and Corporate Performance. Journal of Political Economy 104, 724-746.

Paish, G. 1902. The British Railway Position. The Statist, London.

Parker, D. 2004. The UK's Privatization Experiment: the Passage of Time Permits a Sober Assessment. CESIFO Working Paper No. 1126. Phelps-Brown, E.H. and Handfield-Jones, S.J. 1952. The Climacteric of the 1890s: a Study in the Expanding Economy. Oxford Economic Papers 4, 266-307.

Saul, S.B. 1968. The Myth of the Great Depression, 1873-1896. Macmillan, London. 
Table 1. Estimates of Average Haul Length (miles) and Receipts/Ton-Mile (d)

\begin{tabular}{|c|c|c|c|c|c|c|c|c|}
\hline \multirow[b]{2}{*}{ Period } & \multicolumn{2}{|c|}{ Hawke } & \multicolumn{2}{|l|}{ Cain } & \multicolumn{4}{|c|}{ Present Study } \\
\hline & Haul & Receipts & Haul & Receipts & Minerals Haul & $\begin{array}{l}\text { Merchandise } \\
\text { Haul }\end{array}$ & $\begin{array}{l}\text { Average } \\
\text { Haul }\end{array}$ & Receipts \\
\hline 1847 & 22.5 & 1.65 & & & & & & \\
\hline 1865 & $33.0^{2}$ & 1.21 & & & 31.3 & 25.3 & 29.0 & 1.27 \\
\hline 1871 & 33.5 & 1.14 & 30 & 1.28 & 33.6 & 27.2 & 31.1 & 1.14 \\
\hline 1880 & 37.4 & 0.98 & 30 & 1.22 & 30.3 & 34.0 & 31.4 & 1.11 \\
\hline 1911 & & & 28 & 1.00 & 24.8 & 33.6 & 26.6 & 1.05 \\
\hline
\end{tabular}

\section{Notes}

1. Foreman-Peck (1991) accepted Cain's estimates for average haul length.

2. Hawke's estimates imply a haul length for minerals of 31.5 miles in 1865.

Sources: derived from Hawke (1970), Cain (1988) and see text for present study. 
Table 2 Inputs and outputs in British railways, 1852-1912 (1912 = 100)

\begin{tabular}{|c|c|c|c|c|c|c|c|c|}
\hline Year & $\begin{array}{c}(1) \\
\text { Capital }\end{array}$ & $\begin{array}{c}(2) \\
\text { Labour }\end{array}$ & $\begin{array}{l}(3) \\
\text { Coal }\end{array}$ & $\begin{array}{c}(4) \\
\text { Total } \\
\text { input }\end{array}$ & $\begin{array}{c}(5) \\
\text { Passenger } \\
\text { train } \\
\text { miles } \\
\end{array}$ & $\begin{array}{c}(6) \\
\text { Mineral } \\
\text { ton } \\
\text { miles }\end{array}$ & $\begin{array}{c}(7) \\
\text { Merchan- } \\
\text { dise } \\
\text { ton miles }\end{array}$ & $\begin{array}{c}\text { (8) } \\
\text { Total } \\
\text { output }\end{array}$ \\
\hline 1852 & 35.6 & 11.0 & 10.8 & 26.5 & 13.5 & 8.1 & 9.1 & 10.7 \\
\hline 1853 & 36.8 & 13.1 & 12.8 & 28.0 & 14.0 & 9.9 & 10.8 & 11.9 \\
\hline 1854 & 38.3 & 14.7 & 15.7 & 29.6 & 14.6 & 11.2 & 12.0 & 12.9 \\
\hline 1855 & 39.6 & 15.9 & 17.7 & 30.9 & 14.9 & 11.4 & 12.2 & 13.2 \\
\hline 1856 & 40.5 & 16.6 & 19.7 & 31.7 & 15.5 & 11.5 & 13.5 & 13.8 \\
\hline 1857 & 41.4 & 17.5 & 21.7 & 32.7 & 16.8 & 13.1 & 14.1 & 15.1 \\
\hline 1858 & 42.3 & 17.8 & 22.6 & 33.4 & 17.7 & 13.7 & 14.8 & 15.8 \\
\hline 1859 & 43.4 & 18.9 & 23.6 & 34.5 & 18.7 & 15.1 & 15.7 & 16.8 \\
\hline 1860 & 44.5 & 18.3 & 23.6 & 35.0 & 19.8 & 17.8 & 17.5 & 18.6 \\
\hline 1861 & 46.3 & 20.8 & 22.6 & 36.9 & 20.1 & 19.0 & 18.3 & 19.3 \\
\hline 1862 & 48.2 & 21.2 & 21.7 & 38.2 & 21.4 & 19.2 & 18.3 & 19.9 \\
\hline 1863 & 50.6 & 21.2 & 21.7 & 39.7 & 22.7 & 20.9 & 20.0 & 21.4 \\
\hline 1864 & 53.4 & 23.3 & 21.7 & 42.2 & 24.9 & 23.4 & 21.8 & 23.5 \\
\hline 1865 & 56.8 & 25.4 & 21.7 & 45.0 & 26.6 & 24.5 & 23.2 & 25.0 \\
\hline 1866 & 59.5 & 28.2 & 19.7 & 47.7 & 27.4 & 26.5 & 26.6 & 26.9 \\
\hline 1867 & 61.0 & 29.6 & 18.7 & 49.0 & 28.1 & 28.5 & 30.1 & 28.8 \\
\hline 1868 & 61.7 & 30.3 & 15.7 & 49.7 & 29.6 & 28.8 & 35.1 & 31.1 \\
\hline 1869 & 62.3 & 31.3 & 21.9 & 50.5 & 30.5 & 30.7 & 29.9 & 30.4 \\
\hline 1870 & 62.8 & 32.7 & 23.7 & 51.4 & 32.7 & 32.4 & 41.1 & 35.3 \\
\hline 1871 & 63.8 & 35.7 & 25.5 & 53.1 & 33.9 & 34.5 & 46.0 & 37.9 \\
\hline 1872 & 64.8 & 40.1 & 27.3 & 55.3 & 35.3 & 38.7 & 49.8 & 40.8 \\
\hline 1873 & 66.1 & 44.6 & 29.1 & 57.7 & 36.0 & 43.4 & 53.8 & 43.6 \\
\hline 1874 & 67.8 & 46.9 & 30.9 & 59.6 & 37.0 & 42.9 & 54.9 & 44.2 \\
\hline 1875 & 69.7 & 49.9 & 32.8 & 61.8 & 38.6 & 46.2 & 55.5 & 45.9 \\
\hline 1876 & 71.4 & 52.5 & 34.6 & 63.9 & 40.4 & 46.6 & 56.4 & 47.1 \\
\hline 1877 & 72.9 & 53.3 & 36.4 & 65.1 & 41.7 & 47.3 & 56.8 & 48.0 \\
\hline 1878 & 74.2 & 53.5 & 38.2 & 66.1 & 43.3 & 45.8 & 56.4 & 48.1 \\
\hline 1879 & 75.1 & 52.3 & 40.0 & 66.3 & 44.1 & 46.9 & 55.7 & 48.5 \\
\hline 1880 & 75.9 & 53.8 & 41.8 & 67.4 & 47.0 & 50.4 & 59.5 & 51.9 \\
\hline 1881 & 77.2 & 55.4 & 43.7 & 68.7 & 48.2 & 52.2 & 60.4 & 53.1 \\
\hline 1882 & 78.3 & 57.5 & 45.5 & 70.2 & 50.6 & 53.6 & 62.4 & 55.1 \\
\hline 1883 & 79.7 & 59.0 & 47.3 & 71.7 & 53.0 & 55.8 & 63.6 & 57.1 \\
\hline
\end{tabular}




\begin{tabular}{|c|c|c|c|c|c|c|c|c|}
\hline Year & $\begin{array}{c}(1) \\
\text { Capital }\end{array}$ & $\begin{array}{c}(2) \\
\text { Labour }\end{array}$ & $\begin{array}{l}(3) \\
\text { Coal }\end{array}$ & $\begin{array}{c}(4) \\
\text { Total } \\
\text { input }\end{array}$ & $\begin{array}{c}(5) \\
\text { Passenger } \\
\text { train } \\
\text { miles }\end{array}$ & $\begin{array}{c}(6) \\
\text { Mineral } \\
\text { ton } \\
\text { miles }\end{array}$ & $\begin{array}{c}(7) \\
\text { Merchan- } \\
\text { dise } \\
\text { ton miles }\end{array}$ & $\begin{array}{c}\text { (8) } \\
\text { Total } \\
\text { output }\end{array}$ \\
\hline 1884 & 81.5 & 59.8 & 49.1 & 73.1 & 55.1 & 53.3 & 62.5 & 57.0 \\
\hline 1885 & 82.7 & 59.7 & 50.9 & 73.9 & 55.9 & 52.4 & 54.9 & 54.7 \\
\hline 1886 & 83.4 & 59.9 & 52.7 & 74.5 & 57.1 & 51.6 & 59.9 & 56.6 \\
\hline 1887 & 83.9 & 61.2 & 54.6 & 75.3 & 58.3 & 53.8 & 61.0 & 58.0 \\
\hline 1888 & 84.4 & 61.7 & 56.4 & 75.8 & 59.5 & 55.5 & 63.7 & 59.9 \\
\hline 1889 & 85.0 & 63.9 & 58.2 & 77.0 & 61.9 & 58.6 & 68.0 & 63.0 \\
\hline 1890 & 85.7 & 67.5 & 60.0 & 78.7 & 64.0 & 60.3 & 69.8 & 64.9 \\
\hline 1891 & 86.9 & 70.6 & 61.8 & 80.6 & 66.0 & 62.1 & 71.2 & 66.7 \\
\hline 1892 & 88.0 & 72.3 & 63.6 & 81.9 & 67.6 & 61.3 & 71.0 & 67.1 \\
\hline 1893 & 88.8 & 72.7 & 65.5 & 82.6 & 68.0 & 56.4 & 69.4 & 65.6 \\
\hline 1894 & 89.6 & 75.0 & 67.3 & 84.0 & 69.2 & 62.2 & 71.1 & 68.1 \\
\hline 1895 & 90.5 & 76.4 & 69.1 & 85.0 & 70.9 & 62.3 & 73.1 & 69.5 \\
\hline 1896 & 91.4 & 79.6 & 70.9 & 86.8 & 74.5 & 65.0 & 77.7 & 73.1 \\
\hline 1897 & 92.6 & 83.4 & 72.7 & 88.8 & 77.7 & 67.7 & 80.2 & 76.0 \\
\hline 1898 & 94.2 & 86.8 & 74.5 & 91.1 & 80.6 & 69.5 & 82.8 & 78.5 \\
\hline 1899 & 95.7 & 90.3 & 76.3 & 93.3 & 83.4 & 74.9 & 86.7 & 82.4 \\
\hline 1900 & 97.0 & 92.6 & 78.2 & 94.9 & 85.0 & 78.5 & 87.6 & 84.2 \\
\hline 1901 & 98.3 & 93.5 & 80.0 & 96.1 & 86.2 & 76.3 & 89.0 & 84.6 \\
\hline 1902 & 99.3 & 94.7 & 81.8 & 97.2 & 87.9 & 80.6 & 89.2 & 86.5 \\
\hline 1903 & 100.4 & 94.7 & 83.6 & 97.9 & 89.5 & 86.9 & 84.6 & 87.3 \\
\hline 1904 & 101.4 & 94.5 & 85.4 & 98.6 & 92.7 & 88.0 & 84.6 & 89.0 \\
\hline 1905 & 102.2 & 94.6 & 87.2 & 99.2 & 94.3 & 90.1 & 86.0 & 90.6 \\
\hline 1906 & 102.8 & 97.1 & 89.1 & 100.5 & 98.0 & 94.7 & 88.0 & 94.0 \\
\hline 1907 & 103.0 & 100.9 & 90.9 & 102.0 & 101.2 & 101.0 & 90.6 & 97.8 \\
\hline 1908 & 102.6 & 99.0 & 92.7 & 101.1 & 102.0 & 96.7 & 87.2 & 96.0 \\
\hline 1909 & 102.0 & 98.1 & 94.5 & 100.5 & 102.0 & 97.4 & 88.3 & 96.5 \\
\hline 1910 & 101.3 & 98.9 & 96.3 & 100.3 & 103.2 & 100.1 & 91.8 & 98.8 \\
\hline 1911 & 100.6 & 99.9 & 98.1 & 100.3 & 104.9 & 102.0 & 95.9 & 101.3 \\
\hline 1912 & 100.0 & 100.0 & 100.0 & 100.0 & 100.0 & 100.0 & 100.0 & 100.0 \\
\hline
\end{tabular}

Source: see text 
Table 3 TFP on British railways, 1852-1912 (1912 = 100)

\begin{tabular}{rrrr}
\hline Year & $\begin{array}{r}\text { Labour } \\
\text { productivity }\end{array}$ & $\begin{array}{r}\text { Capital } \\
\text { productivity }\end{array}$ & TFP \\
\hline 1852 & 97.7 & 30.1 & 40.5 \\
1853 & 91.4 & 32.5 & 42.6 \\
1854 & 88.0 & 33.7 & 43.6 \\
1855 & 82.8 & 33.3 & 42.7 \\
1856 & 83.4 & 34.2 & 43.6 \\
1857 & 86.0 & 36.4 & 46.1 \\
1858 & 88.8 & 37.3 & 47.3 \\
1859 & 89.1 & 38.8 & 48.9 \\
1860 & 101.5 & 41.7 & 53.1 \\
1861 & 92.6 & 41.6 & 52.1 \\
1862 & 93.8 & 41.2 & 51.9 \\
1863 & 101.0 & 42.2 & 53.8 \\
1864 & 101.0 & 44.1 & 55.7 \\
1865 & 98.4 & 44.1 & 55.5 \\
1866 & 95.5 & 45.3 & 56.5 \\
1867 & 97.5 & 47.3 & 58.8 \\
1868 & 102.8 & 50.4 & 62.7 \\
1869 & 97.1 & 48.8 & 60.1 \\
1870 & 108.2 & 56.2 & 68.8 \\
1871 & 106.3 & 59.5 & 71.5 \\
1872 & 101.7 & 62.9 & 73.8 \\
1873 & 97.7 & 65.9 & 75.6 \\
1874 & 94.2 & 65.1 & 74.1 \\
1875 & 92.1 & 65.9 & 74.2 \\
1876 & 89.7 & 65.9 & 73.7 \\
1877 & 89.9 & 65.8 & 73.6 \\
1878 & 90.0 & 64.9 & 72.9 \\
1879 & 92.7 & 64.6 & 73.2 \\
1880 & 96.3 & 68.3 & 76.9 \\
1881 & 95.9 & 68.8 & 77.2 \\
1882 & 95.9 & 70.4 & 79.7 \\
1883 & 96.8 & 71.7 & 78.0 \\
1884 & 95.4 & 70.0 & 74.0 \\
1885 & 91.6 & 66.2 &
\end{tabular}




\begin{tabular}{rrrr}
\hline Year & $\begin{array}{r}\text { Labour } \\
\text { productivity }\end{array}$ & $\begin{array}{r}\text { Capital } \\
\text { productivity }\end{array}$ & TFP \\
\hline 1886 & 94.6 & 67.9 & 76.0 \\
1887 & 94.9 & 69.1 & 77.1 \\
1888 & 97.1 & 70.9 & 78.9 \\
1889 & 98.6 & 74.2 & 81.9 \\
1890 & 96.2 & 75.8 & 82.5 \\
1891 & 94.4 & 76.7 & 82.7 \\
1892 & 92.8 & 76.3 & 81.9 \\
1893 & 90.2 & 73.8 & 79.3 \\
1894 & 90.7 & 76.0 & 81.1 \\
1895 & 91.0 & 76.8 & 81.7 \\
1896 & 91.9 & 80.0 & 84.3 \\
1897 & 91.2 & 82.1 & 85.6 \\
1898 & 90.5 & 83.4 & 86.2 \\
1899 & 91.1 & 86.1 & 88.3 \\
1900 & 91.0 & 86.8 & 88.7 \\
1901 & 90.5 & 86.1 & 88.0 \\
1902 & 91.3 & 87.1 & 89.0 \\
1903 & 92.2 & 86.9 & 89.1 \\
1904 & 94.1 & 87.7 & 90.2 \\
1905 & 95.8 & 88.7 & 91.4 \\
1906 & 96.8 & 91.4 & 93.5 \\
1907 & 96.9 & 94.9 & 95.9 \\
1908 & 96.9 & 93.5 & 94.9 \\
1909 & 98.4 & 94.6 & 96.0 \\
1910 & 99.9 & 97.6 & 98.5 \\
1911 & 101.4 & 100.7 & 101.0 \\
1912 & 100.0 & 100.0 & 100.0 \\
\hline 50410.5 & & &
\end{tabular}

Source: see text 
Table 4 Estimates of Output (Y), Total Factor Input (TFI), Total Factor Productivity (TFP), and Labour Productivity (Y/L) Growth Rates (\% per year)

\begin{tabular}{|c|c|c|c|c|c|c|c|c|c|c|c|c|}
\hline \multirow[t]{2}{*}{ Period } & \multicolumn{4}{|c|}{ Hawke } & \multicolumn{4}{|c|}{ Foreman-Peck } & \multicolumn{4}{|c|}{ Present Study } \\
\hline & $Y$ & TFI & TFP & $\mathrm{Y} / \mathrm{L}$ & $\mathrm{Y}$ & TFI & TFP & $\mathrm{Y} / \mathrm{L}$ & $\mathrm{Y}$ & TFI & TFP & $\mathrm{Y} / \mathrm{L}$ \\
\hline $1850-60^{1}$ & 9.4 & 4.2 & 5.2 & 1.1 & & & & & 7.2 & 3.5 & 3.7 & 0.6 \\
\hline $1870-80$ & 5.5 & 2.6 & 2.9 & 1.1 & 3.8 & 2.6 & 1.2 & -0.7 & 3.9 & 2.8 & 1.1 & -1.2 \\
\hline $1880-90$ & 3.5 & 1.6 & 1.9 & 1.2 & 2.9 & 1.7 & 1.2 & 0.6 & 2.3 & 1.6 & 0.7 & 0.0 \\
\hline $\begin{array}{l}1890- \\
1900\end{array}$ & & & & & 2.5 & 2.1 & 0.4 & -0.9 & 2.6 & 1.9 & 0.7 & -0.6 \\
\hline
\end{tabular}

Notes

1.The period in the present study starts from 1852 rather than 1850.

Sources: derived from Foreman-Peck (1991), Hawke (1970), and Tables 2 and 3. 
Table 5. Estimates of Company-Level Output (Y) Total Factor Input (TFI) and Total Factor Productivity (TFP) (\% per year)

\begin{tabular}{|c|c|c|c|c|c|c|c|c|c|}
\hline \multirow[b]{2}{*}{ COMPANY } & \multicolumn{3}{|c|}{ 1893-1912 } & \multicolumn{3}{|c|}{$1893-1900$} & \multicolumn{3}{|c|}{ 1900-1912 } \\
\hline & $\mathrm{Y}$ & TFI & TFP & & TFI & TFP & $\mathrm{Y}$ & TFI & TFP \\
\hline Great Eastern & 2.2 & 1.1 & 1.1 & 4.2 & 2.6 & 1.7 & 1.1 & 0.5 & 0.6 \\
\hline Great Northern & 1.8 & 1.4 & 0.4 & 4.4 & 4.0 & 0.5 & 0.3 & 0.2 & 0.1 \\
\hline Great Western & 2.7 & 2.0 & 0.8 & 3.3 & 2.2 & 1.1 & 2.4 & 1.9 & 0.5 \\
\hline $\begin{array}{l}\text { Lancashire and Yorkshire } \\
\text { London, Brighton, and South }\end{array}$ & 1.8 & 1.4 & 0.4 & 2.4 & 1.8 & 0.6 & 1.4 & 1.2 & 0.2 \\
\hline Coast & 1.9 & 1.4 & 0.5 & 3.3 & 2.6 & 0.7 & 1.1 & 0.7 & 0.3 \\
\hline London and North Western & 2.1 & 1.4 & 0.7 & 2.6 & 2.4 & 0.2 & 1.8 & 1.0 & 0.8 \\
\hline $\begin{array}{l}\text { London and South Western } \\
\text { M+S+L (after 1897, Great }\end{array}$ & 2.2 & 1.3 & 0.8 & 3.4 & 2.5 & 0.8 & 1.5 & 0.6 & 0.8 \\
\hline Central) & 4.5 & 4.1 & 0.4 & 6.5 & 6.6 & -0.1 & 3.3 & 2.7 & 0.6 \\
\hline Midland & 1.9 & 1.5 & 0.4 & 4.5 & 3.8 & 0.7 & 0.4 & 0.3 & 0.1 \\
\hline North Eastern & 2.3 & 1.2 & 1.1 & 3.9 & 2.5 & 1.4 & 1.3 & 0.4 & 0.9 \\
\hline South Eastern (+ Chatham after & & & & & & & & & \\
\hline 1899) & 5.2 & 4.6 & 0.6 & 12.4 & 11.4 & 1.0 & 1.0 & 0.5 & 0.4 \\
\hline Taff Vale & 2.1 & 0.9 & 1.2 & 3.5 & 1.5 & 2.1 & 1.3 & 0.5 & 0.8 \\
\hline Caledonian & 2.0 & 1.3 & 0.7 & 3.5 & 2.4 & 1.1 & 1.1 & 0.3 & 0.8 \\
\hline North British & 2.4 & 1.6 & 0.8 & 3.4 & 2.1 & 1.2 & 1.9 & 1.2 & 0.7 \\
\hline Average & 2.4 & 1.7 & 0.7 & 3.9 & 3.0 & 0.9 & 1.5 & 0.9 & 0.6 \\
\hline
\end{tabular}

Source: see Appendix.

Notes: Output consists of passenger train miles, mineral ton miles and merchandise ton miles weighted by the revenue shares in 1882 for Britain's railways as a whole. These weights are $0.43,0.25$ and 0.32 , respectively. We have also experimented with the average revenue shares derived from the sample of the 14 companies alone. The results obtained are similar.

TFI consists of capital, labour and coal weighted by the average cost shares in 1882 for Britain's railways as a whole. These weights are $0.63,0.34$ and 0.03 , respectively. We have also experimented with four inputs including iron \& steel average and the average cost shares derived from the sample of the 14 companies alone. The results obtained are similar.

The average figures in the last row are weighted by average total route miles. 


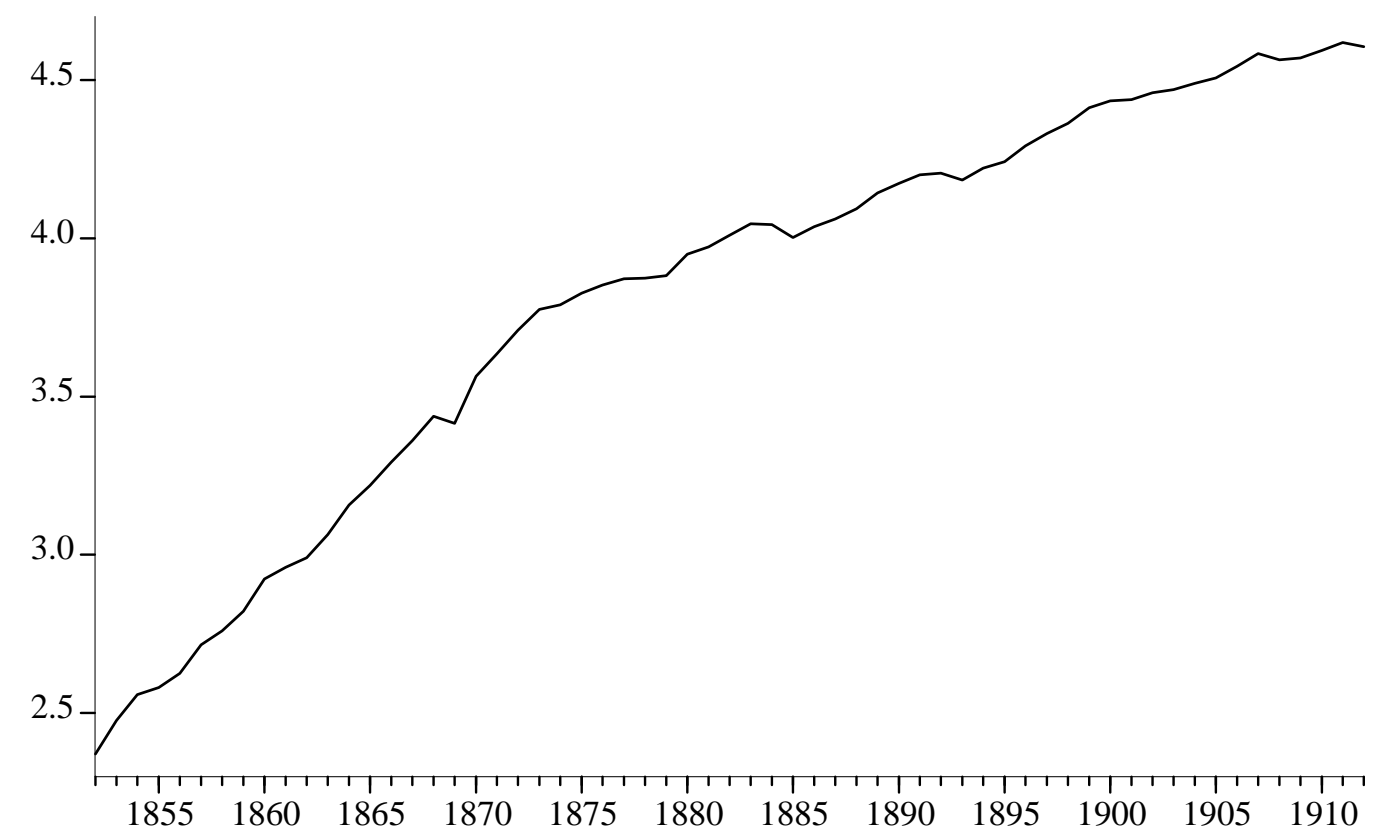

Figure 1. Logarithm of output; 1852 - 1912.

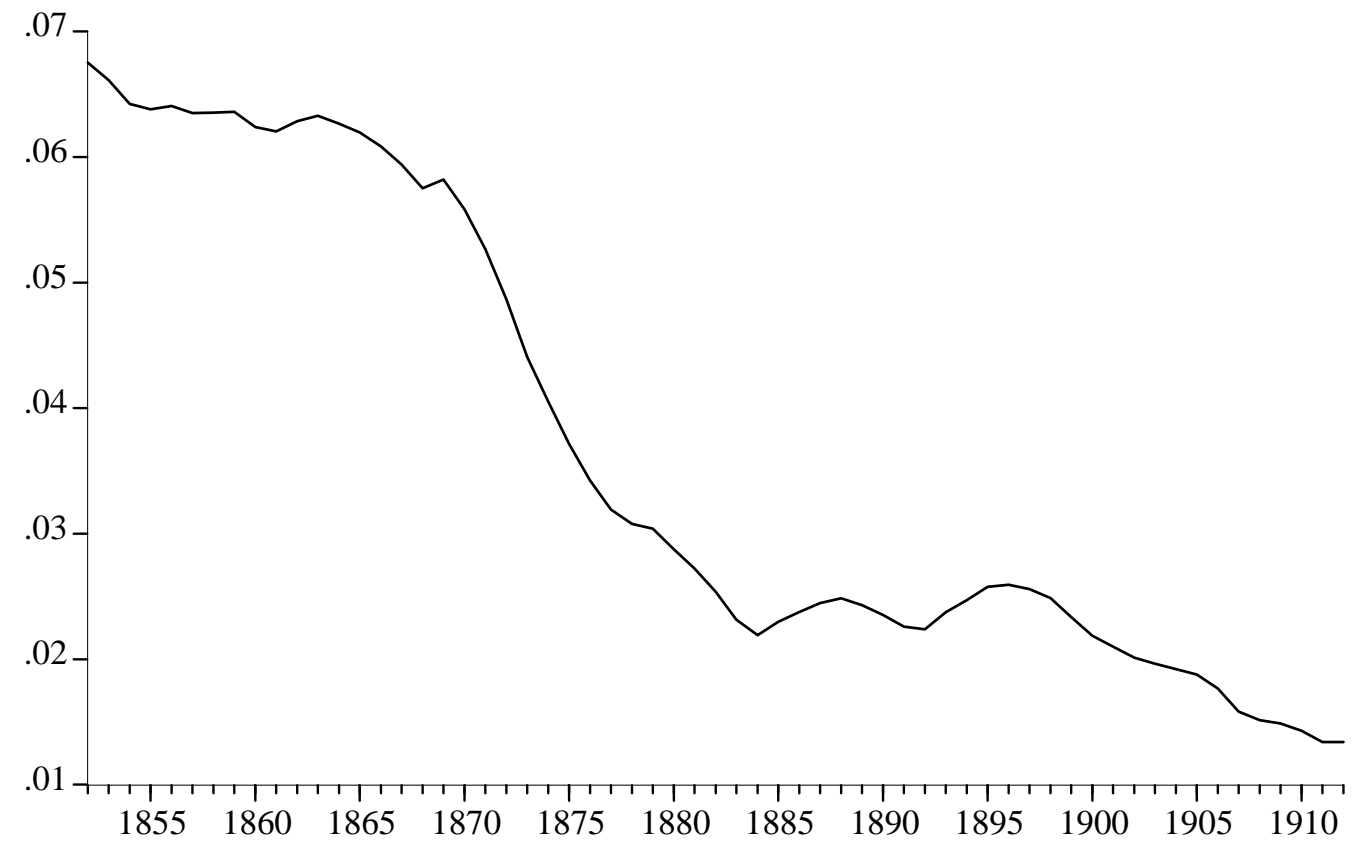

Figure 2. Growth component, $\beta_{t}$, of output: $1852-1912$. 


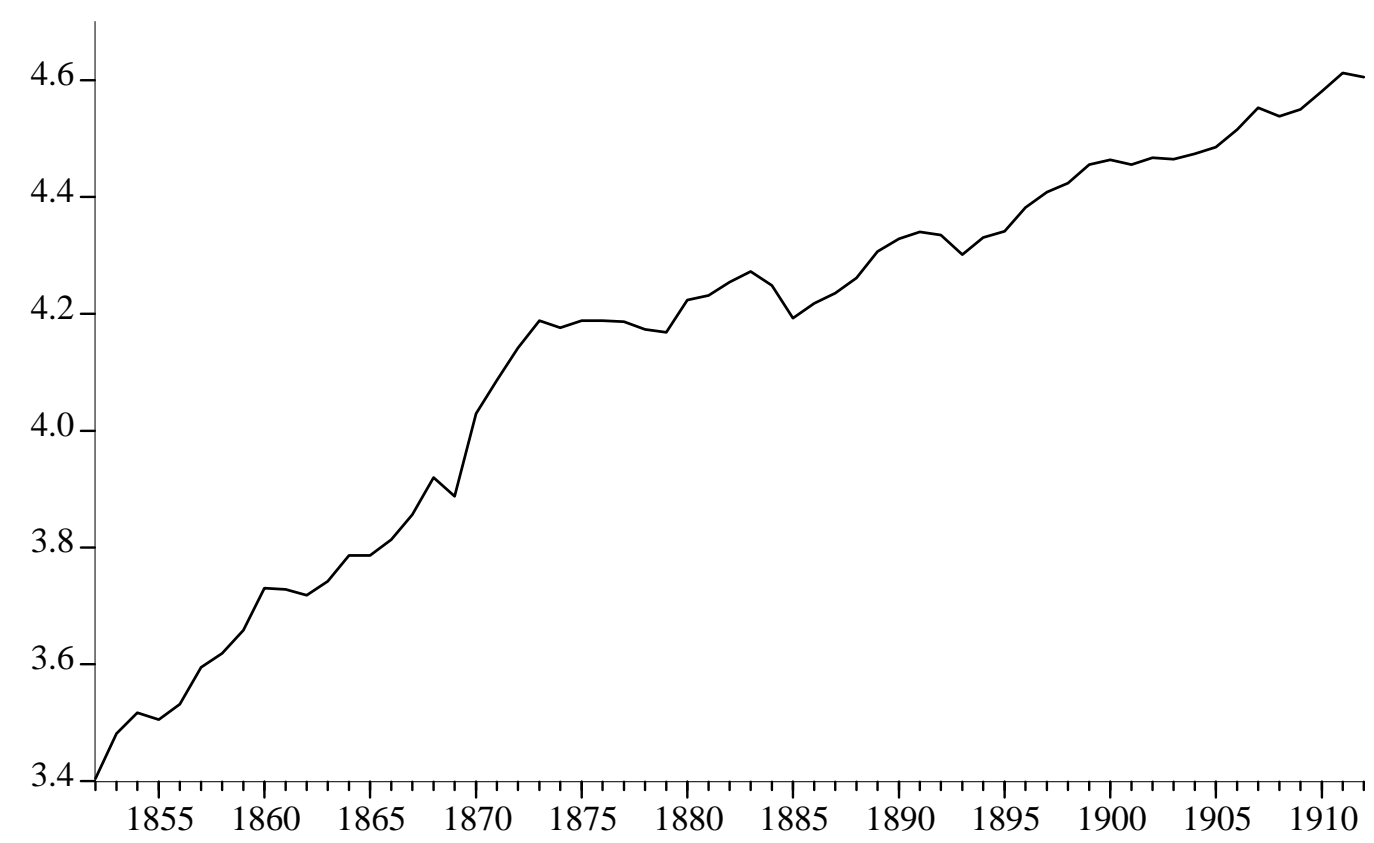

Figure 3. Logarithm of capital productivity

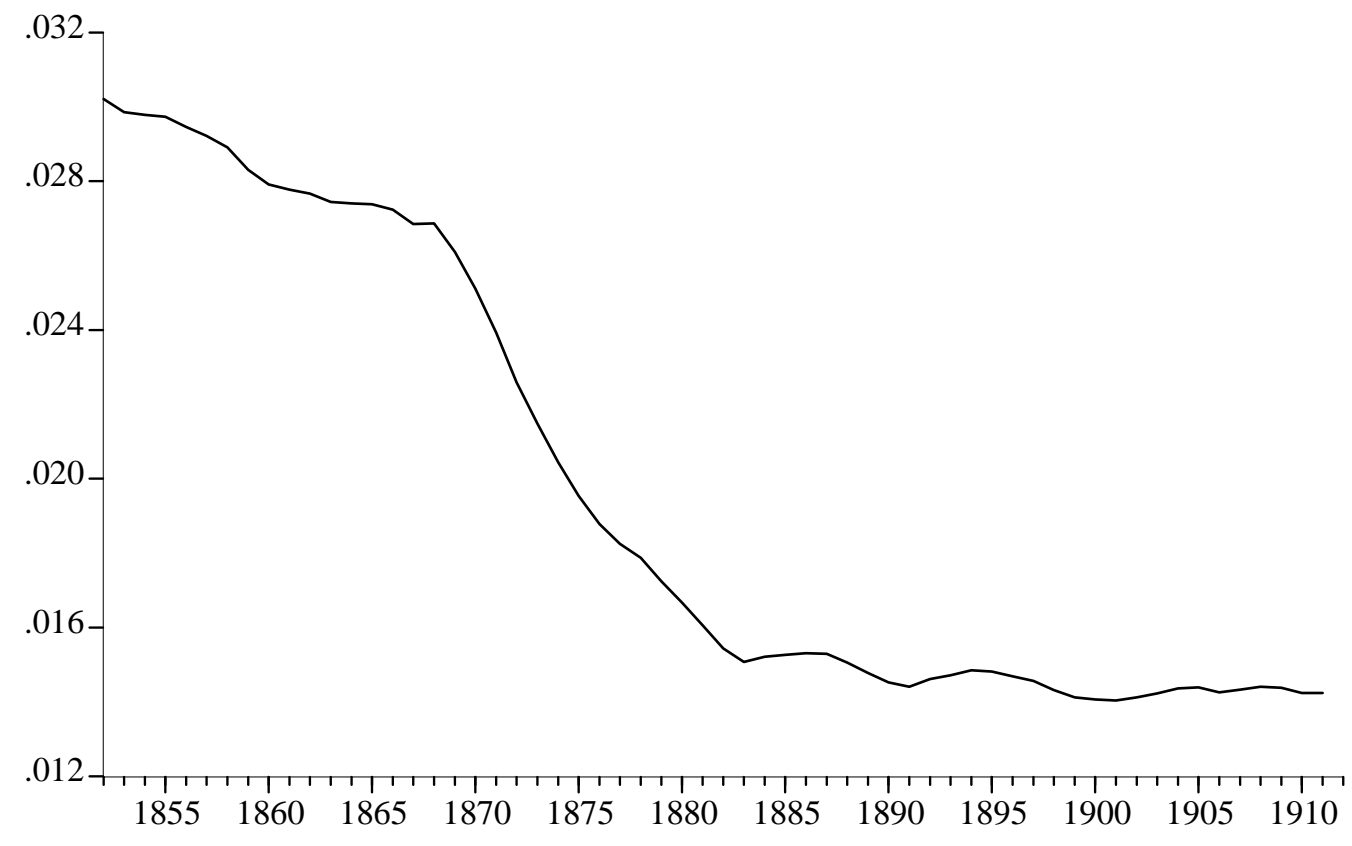

Figure 4. Growth component, $\beta_{t}$, of capital productivity: $1852-1912$. 


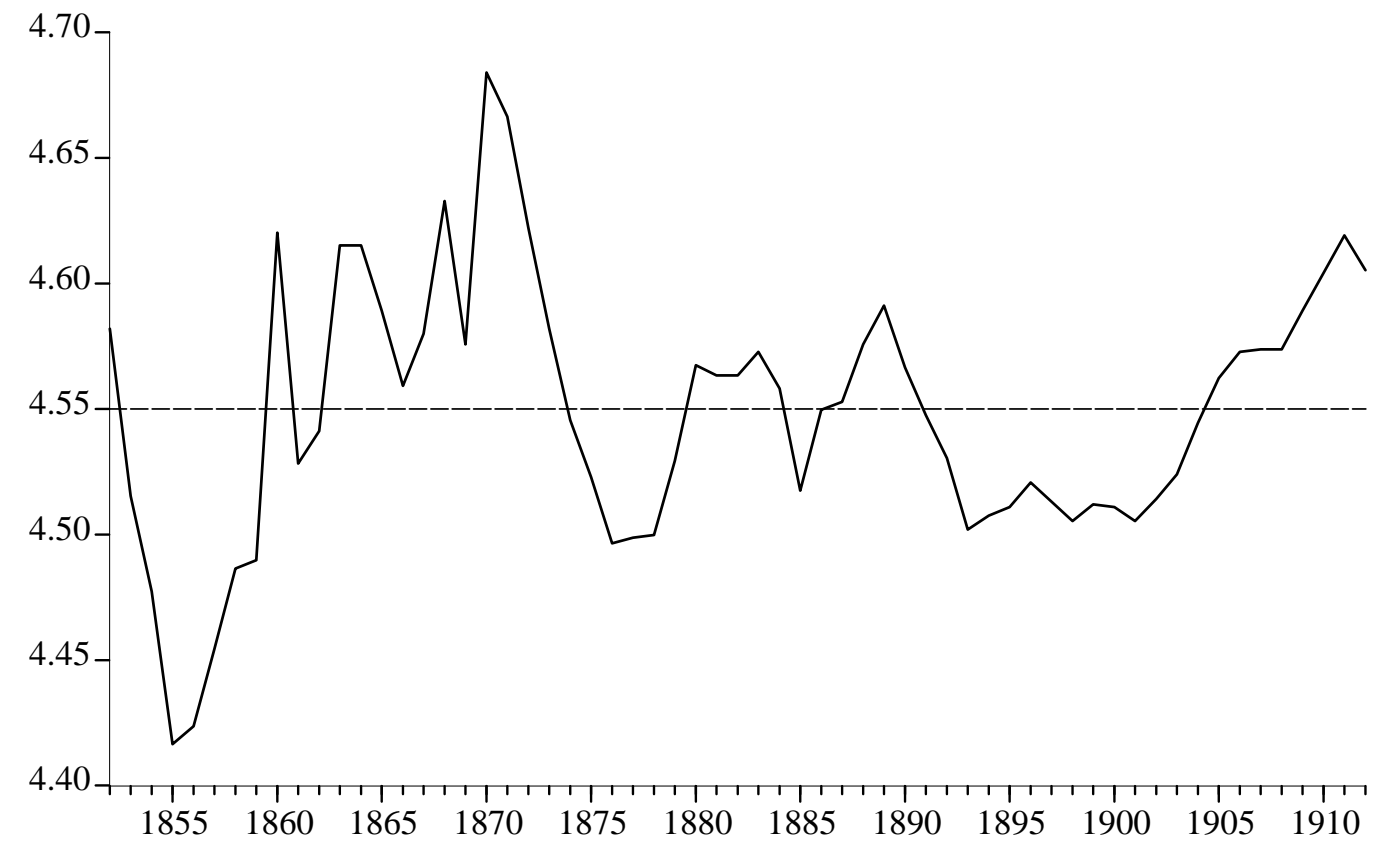

Figure 5. Logarithm of labor productivity with the level $\hat{\mu}=4.55$ superimposed.

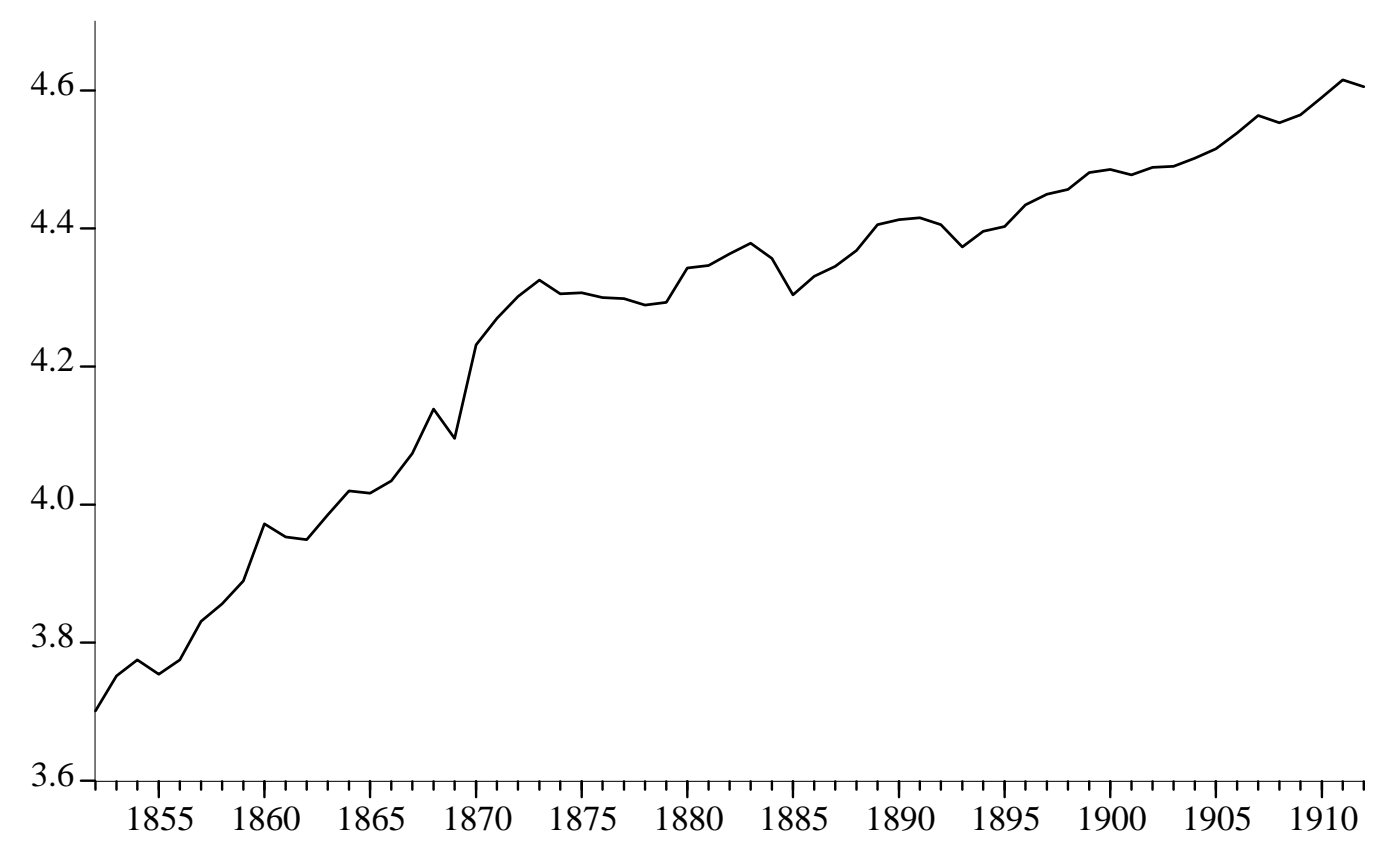

Figure 6 Logarithm of TFP: 1852 - 1912. 


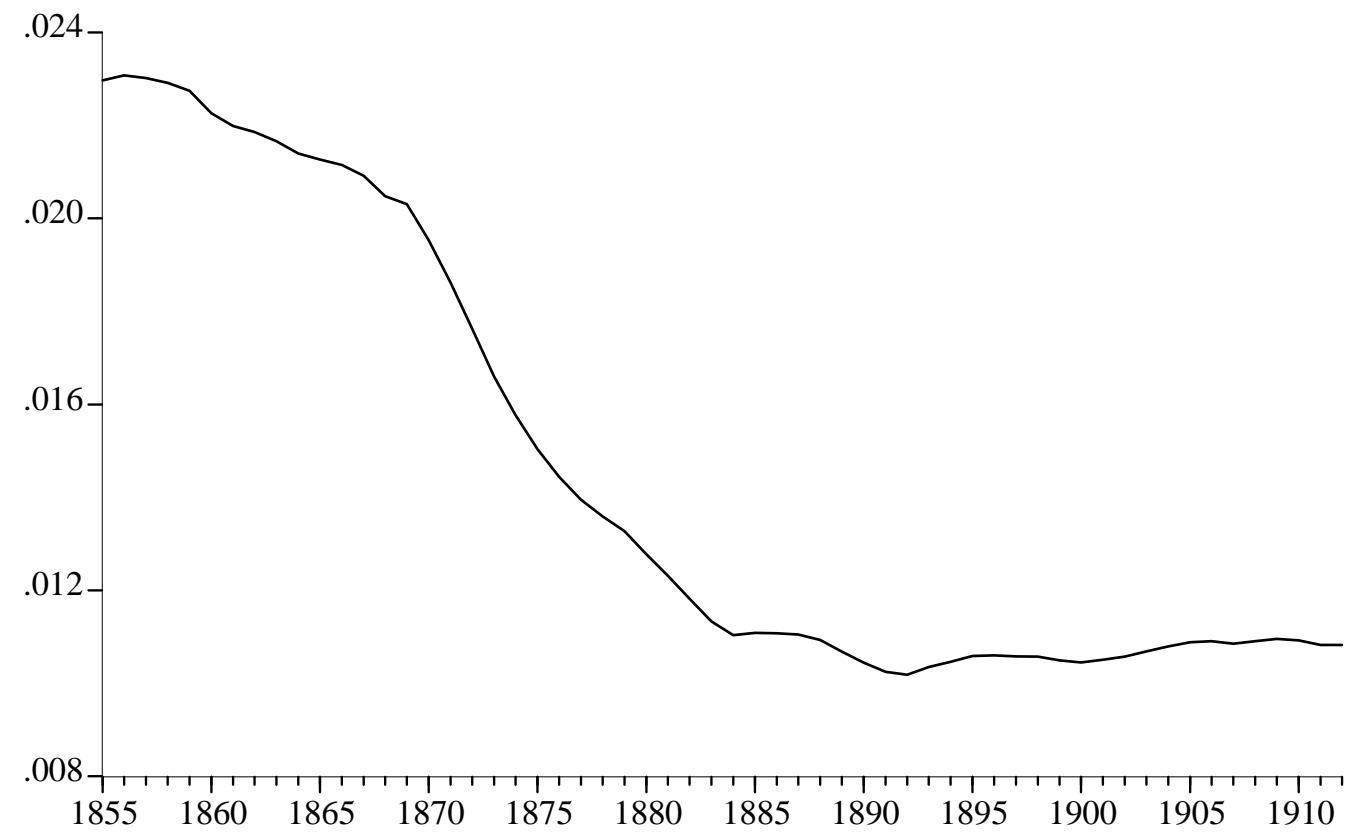

Figure 7 Growth component, $\beta_{t}$, of TFP: $1852-1912$ 


\section{LONDON SCHOOL OF ECONOMICS DEPARTMENT OF ECONOMIC HISTORY}

\section{WORKING PAPERS IN LARGE-SCALE TECHNOLOGICAL CHANGE}

For further copies of this, and to see other titles in the department's group of working paper series, visit our website at:

http://www.Ise.ac.uk/collections/economichistory/

01/04: $\quad$ Steam as a General Purpose Technology: A Growth Accounting Perspective Nicholas F.R. Crafts

(First published as 75/03 in the Department of Economic History Working Papers Series).

02/04: Quantifying the Contribution of Technological Change to Economic Growth in Different Eras: A Review of the Evidence

Nicholas F.R. Crafts

(First published as 79/03 in the Department of Economic History Working Papers Series).

03/04: $\quad$ Regional GDP in Britain, 1871-1911: Some Estimates Nicholas F.R. Crafts

04/04: $\quad$ Market Potential in British Regions, 1871-1931 Nicholas F.R. Crafts

05/04: $\quad$ How did the Location of Industry Respond to Falling Transport Costs in Britain before World War I? Nicholas F.R. Crafts and Abay Mulatu

06/04: Social Savings as a Measure of the Contribution of a New Technology to Economic Growth Nicholas F.R. Crafts

07/05 Total Factor Productivity Growth on Britain's Railways, 18521912: A Reappraisal of the Evidence Nicholas F.R. Crafts, Terence C. Mills \& Abay Mulatu 